\title{
MEĐUVRŠNJAČKI PRIJATELJSKI ODNOSI U RAZREDNOM ODJELU
}

\author{
Ante Kolak, Ivan Markić \\ Filozofski fakultet, Sveučilište \\ u Zagrebu, Hrvatska \\ akolak@ffzg.hr; imarkic@ffzg.hr
}

Primljeno: 29. 1. 2020.

\begin{abstract}
Ovaj rad usmjeren je na proučavanje prijateljskih odnosa unutar razrednog odjela. Odnosi među vršnjacima izuzetno su važni u školskom razdoblju, a nedostatak ili trajne teškoće u prijateljskim odnosima mogu se reflektirati na uspjeh učenika, usvajanje nastavnih sadržaja, sliku učenika o sebi, socijalni status i socijalni uspjeh itd. Cilj empirijskog dijela rada je ispitati kvalitetu prijateljskih odnosa unutar razrednog odjela u kategoriji 'najbolji prijatelj'. Iz cilja istraživanja proizašla su tri istraživačka pitanja: Kakav je profil prijateljskih odnosa u kategoriji 'najbolji prijatelj'? Kako izgleda hijerarhijska struktura dimenzija kvalitete prijateljstva u ponuđenim kategorijama? Koje karakteristike opisuju najboljeg prijatelja i idealnog prijatelja? Rezultati istraživanja utvrđuju dva profila: opći te profil blizine i roditeljske uključenosti. Utvrđivanje hijerarhijske strukture ukazalo je na važnost brige i priznanja (dječaci) te pouzdanosti i rješavanja problema (djevojčice). Vrh hijerarhijske ljestvice zauzimaju dimenzije priznanja $i$ pouzdanosti. Kao najznačajnije karakteristike koje opisuju najboljeg prijatelja ističu se razgovor $i$ zajedničko provođenje vremena, povjeravanje i pomoć, a u idealnom prijateljstvu izdvajaju se moralne vrijednosti prijatelja.
\end{abstract}

Ključne riječi: međuvršnjački odnosi, kvaliteta prijateljstva, razredni odjel, prijateljski profil

\section{Uvodna razmatranja}

Lijepo je biti prijatelj i imati prijatelja. Ove riječi ukazuju na razloge zbog kojih tijekom života pronalazimo i održavamo prijateljstvo. Tražiti prijatelja, biti prijateljem i imati prijatelja cjeloživotni je poziv 
svakoga od nas. Od ranog djetinjstva pa sve do smrti, u interakciji s drugima tražimo osjećaje bliskosti i sigurnosti koji se stječu prijateljstvom. Prijateljstvo kao fenomen predmet je proučavanja u filozofiji, povijesti, teologiji, pedagogiji, sociologiji, znanosti o književnosti, psihologiji i drugim znanostima. Povijesno gledano, analiza prijateljskih odnosa ima svoje duboke korijene. Iz razdoblja antike izdvajamo Aristotela koji analizira motive različitih oblika prijateljevanja, primjerice korist, užitak i krepost. Važnost prijateljstva jasno je vidljiva u Bibliji u kojoj Isus svoje učenike naziva prijateljima i navodi kako »nema veće ljubavi nego život svoj dati za svoje prijatelje« (Ivan 15, 9-17), a što je u suglasju s Aristotelovim promišljanjem o istinskom prijateljstvu koji se po njemu ostvaruje kroz krepost i nesebičnu dobrotu (Vučetić, 2007). U djelu Antoinea de Sainta-Exupéryja Mali princ, po mnogima jednoj od najboljih knjiga 20. stoljeća, izvrsno je prezentirana potraga za prijateljstvom, kao i osjećaj usamljenosti. Biti prijatelj u tom smislu može značiti ne biti sam. Iz potrage glavnog lika za prijateljem vidljive su dimenzije prijateljstva koje su potvrdili i znanstvenici. Mali princ traži prijatelja s kojim će moći razgovarati, koji će ga moći razumjeti, izdvaja se važnost posvećenog vremena u prijateljstvu, kao i kategorije privrženosti, pažnje i nježnosti te motiv traženja prijatelja na pogrešnom mjestu. Sve te dimenzije prijateljstva vidljive su i u mnogim drugim djelima svjetske književnosti. U znanosti pak, fenomen prijateljstva u području međuvršnjačkih odnosa predmet je izučavanja psihologije, sociologije, a sve više i pedagogije te edukacijsko-rehabilitacijske znanosti koje fenomenu prijateljstva prilaze svaka sa svojim specifičnim načinom i interesom istraživanja.

Prijateljstvo i potraga za prijateljem ima svoje razvojne obrasce te bismo prijateljstvo mogli definirati različito ovisno o uzrastu na koji se odnosi. Faza dojenačke dobi usmjerena je isključivo na interakciju s roditeljima (starateljima). Dijete u ovoj fazi zadovoljava svoju potrebu za bliskošću, sigurnošću i zaštitom. U vrijeme predškolske dobi, tj. ranog djetinjstva, vršnjaci počinju dobivati sve veći značaj. Razvija se simbolička igra i mogućnost zajedničkog rješavanja problema, a djeca uče modeliranjem, imitacijom, promatranjem te na simbolički način. Prijateljstva u ovoj fazi nemaju odliku trajnosti i vezana su uz različite situacijske čimbenike od kojih je najčešća igra, tako da prijateljstvo može trajati onoliko dugo koliko i zajednička aktivnost igre. Rawlins 
(1992) navodi kako su u tom vremenu djeca prijatelji s onom djecom s kojom su trenutno u interakciji te kako tada počinje učenje kontrole vlastitih emocija. U razdoblju srednjeg djetinjstva, na koje su posebno usmjereni autori ovoga rada, dolazi do složenijih oblika ponašanja i interakcije djeteta. Razvija se samopoimanje i samopoštovanje, moralno rasuđivanje i prosocijalno ponašanje. Tijekom srednjeg djetinjstva dijete većinu slobodnoga vremena provodi s vršnjacima čime zadovoljava potrebu za intimnošću, formira sliku o sebi, stječe socijalne vještine, uči pomagati, dijeliti i surađivati (Klarin, 2006) te prema prijateljima iskazuje sviđanje i podršku. Hartup (1984; prema Klarin, 2000) navodi da je srednje djetinjstvo vrijeme kvalitativnih i kvantitativnih promjena u interakciji dijete-dijete, ali i vrijeme kada vršnjaci u djetetovom životu zauzimaju ključno mjesto. Budući da dijete provodi sve više vremena s vršnjacima, od velikog je značaja da bude prihvaćeno i od strane vršnjačke skupine (Asher i Parker, 1989). Na važnosti dobivaju intimnost, odanost, povjerenje i bliskost kao bitne osobine odnosa s prijateljem (Turnball, Blue-Banning i Pereira, 2000), a najboljim prijateljem naziva se osoba u koju dijete ima najviše povjerenja, koja je spremna na suradnju, koja pruža zaštitu i potporu te suosjeća (Berndt, 1996, prema Klarin, 2006). Istraživanja pokazuju kako djeca bez najboljih prijatelja (čak i u slučaju kada imaju prijatelje) iskazuju višu razinu usamljenosti u odnosu na one koji imaju najboljeg prijatelja, bez obzira na njihov socijalni status (Parker i Asher, 1993). Navedene će se spoznaje o prijateljskim odnosima značajno reflektirati na empirijski dio rada, s obzirom da je predmet proučavanja međuvršnjačkih odnosa u ovome radu isključivo usmjeren na međuvršnjački prijateljski odnos s najboljim prijateljem odnosno najboljom prijateljicom. Za potrebe ovoga rada, prijateljski odnos s najboljim prijateljem u razvojnoj dobi srednjeg djetinjstva određujemo kao oblik dijadnog interpersonalnog odnosa između dvije bliske osobe zasnovan na uzajamnom sviđanju, obostranoj privlačnosti, poštovanju i uvažavanju unutar kojeg dolazi do emocionalne potpore, intimiteta, zadovoljstva i uživanja u društvu, a koji se realizira zajedničkim provođenjem vremena, raznim aktivnostima, zabavi i uspješnim rješavanjem mogućih problema. Navedeni odnos razlikuje se od odnosa s drugim prijateljima i vršnjacima koji ne moraju zadovoljavati ovako visoke zahtjeve, kao i od odnosa s roditeljima. 
Prijateljski odnos i veza s bliskom osobom iste dobi od iznimne su važnosti za ostvarivanje primarnog socijalnog iskustva te predstavljaju osnovu putem koje se dijete uči suočavati s konfliktnim situacijama (Berndt, 1983, prema Klarin, 2000). Dok vrijeme provodi s najboljim prijateljem, dijete pokazuje sreću i izbjegava druge obveze, želeći što više vremena provesti u društvu osobe koja ga podržava. Dobrobiti koje donosi prijateljstvo su: emocionalna sigurnost, pozitivna slika o sebi, zadovoljstvo, socijalna kompetencija, zadovoljenje potreba za intimnošću te usvajanje prosocijalnih normi ponašanja. Socijalna interakcija između prijatelja je bogatija, što se očituje većoj količini razgovora i kooperativnog ponašanja. Na prijateljstva u razdoblju srednjeg djetinjstva utječu i neki drugi vanjski čimbenici poput mjesta stanovanja, socijalnog statusa ili zajedničkih izvanškolskih aktivnosti (Rawlins, 1992). To je razdoblje kada djeca postaju učenici te se uključuju u obvezni sustav odgoja i obrazovanja u vidu pohađanja osnovne škole. U osnovnoj školi učenici provedu ukupno oko 7000 sati (Bošnjak, 1997), a tijekom navedenog vremena 20 do $30 \%$ djece doživi neki od oblika otežane prilagodbe koji može utjecati na daljnji emocionalni i akademski razvoj (Achenbach i Edelbrock, 1981). Jedna od temeljnih funkcija osnovne škole je ona socijalizacijska, a nju su razmatrali Durkheim navodeći kako je škola »most između pojedinca i društva« - ili primjerice Dewey, koji je smatrao da je »škola društvo u malom« te da se u njoj uče najvažnija pravila života (Dewey, 2007). Prijelaz iz faze ranog u fazu srednjeg djetinjstva karakterizira i bitna promjena odgojno-obrazovne sredine djeteta - ono prelazi iz obitelji/ustanove predškolskog odgoja (vrtića) u školu/razredni odjel. Navedena promjena često je praćena i promjenom strukture odgojne skupine dječjeg vrtića u odnosu na razredni odjel škole. Promjena članova grupe i stvaranje nove razredne zajednice može biti uzrok promjenama u prijateljstvu ili čak prekidu prijateljstva. Istraživanja pokazuju kako promjena sredine može uzrokovati promjene i u prijateljskim odnosima. Ladd i Price (1987) tako navode da djeca koja su zajedno pohađala ustanovu predškolskog odgoja, a zajedno su i u razrednom odjelu, postaju socijalno prihvaćenija i manje odbijana te imaju pozitivnije stavove prema školi. Istraživanja su također pokazala da između djece koja imaju prijatelje i djece koja ih nemaju postoje razlike u prosocijalnom ponašanju (Bowker, 2006; Glick i Rose, 2011; McGuire i Weisz, 1982, prema Trbojević i Petro- 
vić, 2014) te socijalnoj prihvaćenosti i vidljivosti u razrednom odjelu (Vaughn et al., 2000; Wentzel et al., 2003, prema Trbojević i Petrović, 2014). Jedan od temeljnih uvjeta za izgradnju odnosa prijateljstva jest blizina ljudi i komuniciranje s njima, što razredni odjel svakako omogućuje. Istraživanja su pokazala da ako djeca ili stariji žele stvoriti veze potrebne za prijateljstvo, oni moraju imati stalni pristup jedno drugome. Iz toga slijedi da će učenici koji idu u razred ili školu zajedno sa svojim susjedima najvjerojatnije stvoriti čvrstu vezu koja će završiti prijateljstvom (Grenot-Scheyer, Coots i Falvey, 1989; Steinback i Steinback, 1990, prema Pearpoint, Forest i O’Brien, 1997). Razredni odjel stoga ima veliku važnost pri stvaranju prijateljskih odnosa i potvrđuje svoju kompenzacijsku, zaštitničku i socijalizacijsku zadaću (Kiper i Mische, 2008).

Istraživanja o prijateljstvu najčešće su usmjerena na utvrđivanje kvalitete prijateljstva (Ladd, 1990; Wied, Branje i Meeus, 2007; Ledbetter, Griffin i Sparks, 2007), na popularnost (Putarek i Keresteš, 2012), doživljaj prijateljstva i ponašajne korelate (Klarin, Proroković i Šimić Šašić, 2010), utjecaj prijateljstva na neke druge oblike ponašanja učenika, kao npr. nasilno ponašanje (Velki i Vrdoljak, 2011), na ostvarivanje prijateljskih odnosa učenika s posebnim potrebama, bilo da je riječ o učenicima s teškoćama u razvoju (Žic Ralić i Ljubas, 2013; Marton et al., 2015; Krampač-Grljušić i Kolak, 2018) ili darovitim učenicima (Bedeković, Jurčić i Kolak, 2009; Majstrović, 2015), zatim na strategije održavanja prijateljstva i zadovoljstvo prijateljskim odnosom (Huić i Smolčić, 2015) ili na socijalne karakteristike djece koja uspostavljaju prijateljski odnos (Klarin, 2002a; Klarin 2002b; Trbojević i Petrović, 2014). Prilikom potrage za empirijskim nalazima uočen je izostanak studioznijih istraživanja o prijateljskom odnosu specifično usmjerenom na odnos s najboljim prijateljem. Iako se veliki broj istraživanja bavio različitim karakteristikama i odrednicama prijateljstva, mali je broj empirijskih nalaza koji utvrđuju jasan profil najboljeg prijatelja, što se reflektiralo na jedno od istraživačkih pitanja empirijskog dijela ovoga rada. Istraživanja o prijateljstvu često su usmjerena na utvrđivanje razlika i povezanosti između postavljenih varijabli. Jedna od najčešćih je utvrđivanje spolnih razlika. Istraživanja su pokazala kako dječaci više od djevojčica preferiraju nezavisnost u prijateljstvu te su spremniji prekinuti prijateljstvo u slučaju osjećaja gubitka nezavisnosti. Djevojčice 
imaju stabilnije i čvršće prijateljske veze (češće se međusobno biraju za najbolje prijatelje) (Cillessen i Rose, 2005) i manji broj prijatelja od dječaka. One su više okrenute prema intimnosti, a kao bitne odrednice prijateljstva ističu osjećajnost, ekskluzivnost, zajedničku aktivnost i iskrenost, dok su dječaci više orijentirani na zajedničke aktivnosti (Berndt, 1982, prema Aukett, Ritchie i Mill, 1988).

Takvi socijalni zahtjevi zadržavaju se i tijekom kasnijega razvoja, što rezultira različitim orijentacijama u odnosima s drugima. Lacković-Grgin (2005) tako navodi kako istraživanja u različitim kulturama pokazuju da razlike između muškaraca i žena u preferiranim karakteristikama u prijateljskim odnosima nastaju već u djetinjstvu.

Ispitivanje kvalitete prijateljstva često kao polazište uzima percepciju različitih kvalitetnih aspekata prijateljskog odnosa. Upitnik kvalitete prijateljstva koji su konstruirali Parker i Asher (1993) ispituje odnos s najboljim prijateljem, a namijenjen je djeci osnovnoškolske dobi. Sadrži 40 tvrdnji, npr.: Za vrijeme odmora uvijek smo zajedno; Jedan/jedna drugom/drugoj povjeravamo svoje probleme; Jedna/jedan drugoj/drugom pomažemo u domaćim zadaćama; Povjeravamo jedan/ jedna drugome/drugoj tajne. Zadatak učenika je imenovati najboljeg prijatelja i na skali od pet stupnjeva odgovoriti u kojoj mjeri pojedina tvrdnja opisuje njihov odnos, pri čemu 1 označava »nikada ne vrijedi za tvog prijatelja ili vaš odnos«, a 5 »uvijek vrijedi za tvog prijatelja ili vaš odnos«. Faktorskom analizom upitnika autori su dobili šest faktora: 1) vrednovanje i briga, 2) konflikt i izdaja, 3) rješavanje problema, 4) pomaganje i vođenje, 5) druženje i rekreacija te 6) intimnost i samootkrivanje. Klarin (2000) je konstruirala upitnik kvalitete prijateljstva prema predlošku Parkera i Ashera, pri čemu je od originalnog upitnika zadržala 30 tvrdnji koje faktorskom strukturom daju dva faktora. S obzirom na sadržaj, Klarin (2000) prvi faktor opisuje kao Vrednovanje, emocionalnu potporu i rješavanje konflikta, a drugi kao Pomaganje $i$ dijeljenje. Klarin (2000) je primjenila skraćenu i prevedenu skalu na učenicima 4., 6. i 8. razreda osnovne škole $(\alpha=0,94)$. Upitnik mjeri pozitivne aspekte prijateljske veze, a za rezultat se uzima zbroj procjena na svim tvrdnjama. Veći rezultat označava pozitivniju procjenu kvalitete odnosa s najboljim prijateljem. Neki autori prilikom ispitivanja kvaliteta prijateljstva posebno izdvajaju dostupnost, zajedničke aktivnosti, iskrenost, povjerljivost, odanost, razumijevanje, suosjećanje, 
dijeljenje informacija, smijeh, humor i zabavu (Kolak i Markić, 2018). Različiti kvalitetni aspekti prijateljskih odnosa ukazuju na neke zajedničke čimbenike koji se javljaju u većini istraživanja vezanih uz strukturu prijateljskih odnosa, ali i na izostanak jasne faktorske strukture. Za potrebe ovoga istraživanja izdvajamo sljedeće kategorije: priznanje, briga, pouzdanost, povjerljivost, rješavanje problema, pomoć, zabava, kvalitetno provođenje vremena.

\section{Metodologija empirijskog dijela rada}

Problem ovog istraživanja usmjeren je na prijateljske međuvršnjačke odnose unutar razrednog odjela i to isključivo na odnos s najboljim prijateljem. Cilj empirijskog dijela rada je ispitati kvalitetu i odrednice prijateljskog odnosa unutar razrednog odjela. Iz cilja istraživanja proizašla su tri istraživačka pitanja:

- Kakav je profil prijateljskog odnosa u kategoriji 'najbolji prijatelj'?

- Kako izgleda hijerarhijska struktura dimenzija kvalitete prijateljstva u ponuđenim kategorijama?

- Koje karakteristike opisuju 'najboljeg prijatelj'a i ‘idealnog prijatelja'?

Za odgovaranje na postavljena istraživačka pitanja korištena je kvalitativna metodologija. Instrumentarij čini standardizirani intervju s pitanjima otvorenoga tipa koji svojom strukturom odgovara na postavljena istraživačka pitanja. Cilj intervjua bio je prikupiti podatke i dobiti uzorak mišljenja sudionika istraživanja na temelju kojih smo izdvojili dva profila najboljeg prijatelja, hijerarhijsku strukturu dimenzija prijateljskog odnosa, kao i karakteristike idealnog i najboljeg prijatelja. Standardizirani intervju s pitanjima otvorenog tipa imao je točan način postavljanja pitanja i njihov slijed određen je unaprijed. Svim sudionicima pitanja su postavljana istim redoslijedom. Svi sudionici imali su ista temeljna pitanja. $\mathrm{Na}$ ovaj se način povećala mogućnost usporedbe odgovora te je olakšano organiziranje i analiza podataka. Kako bismo smanjili nedostatke ove vrste intervjua, a to je da standardizirani način postavljanja pitanja može suziti i ograničiti prirodnost i relevantnost pitanja i odgovora, intervju je u određenim segmentima imao obilježja vođenog intervjua. Problemi koji su nastali tijekom intervjua specifici- 
rani su u obliku zadanog okvira pomoću razgovora koji je bio određen novonastalom situacijom. Intervju se sastojao od sljedećih vrsta pitanja: opisna pitanja (opiši kako je izgledao proces odluke kojim si nekoga proglasio najboljim prijateljem), pitanja o iskustvima (jesi li imao iskustvo prekida najboljeg prijateljstva? Objasni!), pitanja o ponašanjima (kako se najbolji prijatelj ponaša prema tebi?), pitanja o emocionalnim reakcijama te o vlastitoj prošlosti (opis osjećaja vezanih uz prijateljstvo) i demografska pitanja. Tijekom intervjua vodili smo se načelima etičnosti pri čemu su u uzorak istraživanja ušli samo oni ispitanici za koje su roditelji dali pismenu izjavu i suglasnost za sudjelovanje u istraživanju. Izjava roditelja/skrbnika o pristajanju na sudjelovanje sadržavala je naslov istraživanja, imena istraživača, detaljne informacije o istraživanju, kao i prava sudionika u istraživačkim zadacima. Uzorak je formiran po načelu pristupačnosti odnosno dostupnosti za istraživanje, što ga čini neprobabilističkim, neslučajnim, prigodnim uzorkom, a obuhvatio je dvanaest učenika jednog trećeg razrednog odjela zagrebačke osnovne škole, od kojih je šest bilo djevojčica a šest dječaka. Svi su učenici u uzorku desetogodišnjaci i pripadaju kategoriji srednjeg djetinjstva (od 8 do 14 godina) (Parker i Asher, 1993). Svi učenici su prethodno izjavili da imaju iskustvo najboljeg prijateljstva, što je bio i preduvjet za sudioništvo u istraživanju.

Tablica 1. Struktura uzorka istraživanja po spolu

\begin{tabular}{|c|c|c|c|c|c|c|c|c|c|c|c|c|}
\hline Redni broj & S1 & S2 & S3 & S4 & S5 & S6 & S7 & S8 & S9 & S10 & S11 & S12 \\
\hline Spol & $\breve{Z}$ & $\check{Z}$ & $\check{Z}$ & $\check{Z}$ & $\check{Z}$ & $\check{Z}$ & M & M & M & M & M & M \\
\hline
\end{tabular}

Proces analize intervjua obuhvaćao je: fazu familijarizacije (upoznavanje s podacima, preslušavanje audio zapisa, iščitavanje transkribiranih sadržaja intervjua), fazu identifikacije specifičnih potkategorija unutar postavljenih kategorija, fazu indeksiranja i kodiranja, fazu tabeliranja (prebrojavanje, razvrstavanje i organiziranje potkategorija) te fazu povezivanja i interpretacije.

Kako bismo odgovorili na prvo istraživačko pitanje, odlučili smo izdvojiti dva prijateljska profila. Prvi smo nazvali »opći prijateljski profil« kojeg smo promatrali kroz varijable:

- procjena broja prijatelja, 
- lakoća/težina izbora najboljeg prijatelja,

- spol najboljeg prijatelja,

- dob najboljeg prijatelja,

- duljina trajanja prijateljstva s najboljim prijateljem,

- iskustvo prekida najboljeg prijateljstva, kao i utvrđivanju uzroka prekida.

Drugi prijateljski profil nazvali smo »profil blizine i obiteljske uključenosti«, a promatrali smo ga kroz varijable:

- blizina stanovanja,

- odnos roditelja,

- broj braće i sestara,

- uključenost u obitelj najboljeg prijatelja.

Odgovor na drugo istraživačko pitanje usmjeren je na utvrđivanje hijerarhijske strukture. Hijerarhijska struktura odredila je redoslijed važnosti dimenzija priznanja, brige, pouzdanosti, povjerljivosti, rješavanja problema, pomoći, zabave i kvalitetnog provođenja vremena u prijateljskom odnosu.

Odgovor na treće istraživačko pitanje uključuje pitanja otvorenog tipa koja opisuju karakteristike najboljeg prijatelja, kao i osobine idealnog prijatelja.

\section{Rezultati i interpretacija}

Opći profil prijateljskog odnosa (u daljnjem tekstu PPO) odgovor je na prvo istraživačko pitanje, a predstavljen je kroz šest dimenzija koje odgovaraju postavljenim varijablama u istraživanju. Prvi profil prijateljskog odnosa (PPO1) procjenjuje broj prijatelja. Drugi prijateljski profil (PPO2) razlikuje istospolna prijateljstva u uzorku od prijateljskih odnosa koja uključuju različiti spol. PPO3 predstavlja treći prijateljski profil i razlikuje tri kategorije koje se odnose na težinu odluke o odabiru najboljeg prijatelja: osobe koje su s lakoćom donijele odluku o tome tko im je najbolji prijatelj (»prijateljstvo na prvi pogled «), one kojima je ta odluka bila teška (imali su nedoumica, najbolji prijatelj nije zadovoljavao postavljene kriterije...), kao i one koji se ne mogu odlučiti, tj. odluka im nije bila niti laka niti teška. Četvrti prijateljski profil (PPO4) odnosi se na varijablu dobi te razlikuje tri kategorije: jednu skupinu 
čine oni koji imaju prijatelje iste dobi, drugu oni čiji je najbolji prijatelj generacijski stariji, a treću oni čiji je najbolji prijatelj generacijski mlađi. PPO5 predstavlja peti profil prijateljskog odnosa i odnosi se na dužinu trajanja prijateljstva koja je prezentirana kroz tri kategorije: dugotrajno, kratkotrajno i umjereno. Ovu kategoriju prilagodili smo dobi sudionika istraživanja. Naime, s obzirom na to da uzorak istraživanja čine desetogodišnjaci, kratkotrajnim prijateljstvom kategorizirali smo prijateljski odnos do jedne godine, umjereno dugim onaj odnos koji traje od početka obaveznog školovanja (dulje od godinu, a kraće od tri godine), a dugotrajnim prijateljstvom ono koje izlazi iz okvira stvaranja prijateljstva u školi, dakle dulje od tri godine. Šesti profil (PPO6) odnosi se na iskustvo promjene najboljeg prijatelja. Dihotomno je postavljen i označava postojanje ili nepostojanje ovog iskustva. S obzirom na to da iskustvo promjene prijatelja može biti snažno emocionalno obojano i imati posljedice na socijalni status učenika, dodatnim pitanjem pokušali smo utvrditi razloge ovog prekida. Odgovore smo naknadno razvrstali u tri kategorije.

Tablica 2. Opći prijateljski profil

\begin{tabular}{|c|c|c|c|}
\hline Oznaka & Tema & \multicolumn{2}{|c|}{ Kategorija } \\
\hline \multirow{3}{*}{ PPO 1} & \multirow{3}{*}{$\begin{array}{c}\text { Procjena } \\
\text { broja prijatelja }\end{array}$} & do 20 & 6 \\
\hline & & $21-40$ & 4 \\
\hline & & Više od 40 & 2 \\
\hline \multirow{2}{*}{ PPO 2} & \multirow{2}{*}{ Spol } & Isti & 12 \\
\hline & & Različit & 0 \\
\hline \multirow{3}{*}{ PPO 3} & \multirow{3}{*}{$\begin{array}{c}\text { Težina odluke } \\
\text { odabira najboljeg } \\
\text { prijatelja }\end{array}$} & Laka & 9 \\
\hline & & Umjerena & 1 \\
\hline & & Teška & 2 \\
\hline \multirow{3}{*}{ PPO 4} & \multirow{3}{*}{ Dob } & Mlađi & 0 \\
\hline & & Ista dob & 10 \\
\hline & & Stariji & 2 \\
\hline
\end{tabular}




\begin{tabular}{|c|c|c|c|}
\hline \multirow{3}{*}{ PPO 5} & \multirow{3}{*}{$\begin{array}{c}\text { Dužina trajanja } \\
\text { prijateljstva }\end{array}$} & Dugotrajno & 1 \\
\hline & & Umjereno & 10 \\
\hline & & Kratkotrajno & 1 \\
\hline \multirow{2}{*}{ PPO 6} & \multirow{2}{*}{$\begin{array}{l}\text { Iskustvo promjene } \\
\text { najboljeg prijatelja }\end{array}$} & Postoji & 8 \\
\hline & & Ne postoji & 4 \\
\hline \multirow{3}{*}{$\begin{array}{l}\text { Iskustvo promjene } \\
\text { najboljeg prijatelja }\end{array}$} & \multirow{3}{*}{$\begin{array}{l}\text { Uzroci prekida } \\
\text { najboljeg } \\
\text { prijateljstva }\end{array}$} & Vrtić/škola & 8 \\
\hline & & Odbačenost & 1 \\
\hline & & Svađa & 1 \\
\hline
\end{tabular}

Iz razgovora sa sudionicima intervjua vidljiva je teškoća prilikom definiranja broja prijatelja. Najveći broj učenika izjavljuje da ima do 20 prijatelja. Broj 13 pokazao se kao minimalna vrijednost, a broj 100 kao maksimalna (PPO1). Prilikom vođenja intervjua bilo je vidljivo da učenici zbrajaju prijatelje iz različitih kategorija života (prijatelji iz škole, prijatelji iz susjedstva, prijatelji iz različitih aktivnosti izvan škole...). Broj prijatelja nekim je učenicima statusni znak pri čemu smatraju da oni koji imaju više prijatelja više i vrijede. Stoga je moguće da su u ovoj situaciji neki ispitanici davali socijalno poželjne odgovore kako bi pokazali svoju vrijednost. Sudionici istraživanja u ovom uzorku potvrđuju da svi biraju za najboljeg prijatelja osobu istoga spola. Istraživanja su pokazala da djeca biraju prijatelja na osnovu principa sličnosti kada je u pitanju i prosocijalno ponašanje $u$ ranom osnovnoškolskom uzrastu (Trbojević i Petrović, 2014). Naime, niti jedan sudionik tog istraživanja nije za najboljeg prijatelja odabrao osobu različitog spola. Istraživanja također navode kako je u tom razdoblju istospolno prijateljstvo najčešće (Sullivan, 1953; Bukowski, Brendgen i Vitaro, 2007; Maccoby, 1998) te da se tranzicija s istospolnih prijateljstava prema raznospolnim mijenja u dobi od 13 do 14 godina kada dolazi do značajnih promjena u odnosu na razdoblje predadolescencije (Connolly, Furman i Konarski, 2000; Sippola 1999; Arndorfer i Stormshak, 2008) (PPO2). Pri definiraju prijateljskog profila u ovom segmentu dominira lako uspostavljanje najboljeg prijateljstva. Potrebno je naznačiti da je većina najboljeg prijateljstva u ovom uzorku nastala u dobi dok su učenici bili sedmogodišnjaci odnosno u vrijeme polaska u prvi razred. Rezultati su u skladu s 
drugim istraživanjima koja navode kako tijekom prvih tjedana nastave prijateljstvo i prijatelj ima važnu ulogu u prevenciji i iskazivanju potpore, s obzirom na to da nove situacije i okolina te odsustvo roditelja mogu imati negativne posljedice na prilagodbu. $U$ to vrijeme prijatelji predstavljaju sigurno utočište i polaznu točku za istraživanje okoline (Ladd i Price, 1987; Ladd, 1990), ali imaju i ulogu koja se očituje u stvaranju prilika za uživanje i radost koje mogu povezati sa školskim okruženjem (Marton et al., 2015) (PPO3). Profil dobi u prijateljskom odnosu predstavljaju prilično jedinstveni odgovori. Većina učenika u ovom uzorku ima najboljeg prijatelja iste dobi kao što su i sami učenici. Izuzetak čine samo dvije učenice koje su za najbolju prijateljicu odabrali osobu stariju ili znatno stariju. Riječ je o sudionici istraživanja koja za najbolju prijateljicu bira majku jer smatra da se na vršnjake ne može osloniti i da nisu iskreni, kao i sudionica istraživanja koja bira polusestru (PPO4). Razredni odjel u ovom istraživanju potvrđuje svoje važne i značajne funkcije za razvoj učenika. On ima zaštitničku, kompenzacijsku i socijalizacijsku funkciju. Profil dužine prijateljstva u ovom uzorku odgovara količini provedenog vremena u školi: tri godine. Rezultati upućuju na zaključak da se prva trajnija najbolja prijateljstva stječu u školi. To potvrđuju istraživanja prijateljskih odnosa odraslih osoba koja navode kako oko $20 \%$ trajnih i životnih prijateljstava počinje već u osnovnoj školi (Huić i Smolčić, 2015) (PPO5).

Učenici su iskustvo promjene najboljeg prijatelja iznosili deskriptivno, a sve odgovore mogli smo dihotomno kategorizirali u dvije skupine - na odgovore koji ukazuju na postojanje navedenog iskustva $\mathrm{i}$ na one koji ga negiraju. Rezultati su pokazali da dvije trećine ispitanika ima iskustvo promjene, a jedna trećina nema (PPO6). Analizom rezultata utvrdili smo da je presudan čimbenik kontakt odnosno blizina. Promjena odgojno-obrazovne institucije (u našem slučaju dječji vrtić i osnovna škola) pokazala se kao značajan čimbenik. Učenici su navodili da su prijateljstva iz vrtića vremenom postajala sve manjeg intenziteta zbog sve manje zajedničkih interesa i sve manje vremena provedenog zajedno. Dva su učenika kao prekid naveli drugačije uzroke kao što su neslaganje i svađa, tj. problemi u međusobnim odnosima.

Profil blizine i obiteljske uključenosti drugi je odgovor na prvo istraživačko pitanje o profilu prijateljskog odnosa u kategoriji »najbolji prijatelj«. Promatran je kroz profil blizine stanovanja (u daljnjem tek- 
stu PBS) pri čemu smo razlikovali četiri kategorije poštujući prostorne koncentrične krugove: živi zajedno sa mnom, moj je susjed, živi u istom kvartu i živi u istom gradu. Profil međusobnog odnosa roditelja najboljih prijatelja (PRO) razlikuje poznaničke odnose, prijateljske odnose, odnose bliskih prijatelja i rodbinske odnose. Profil sestara i braće (PSB) razlikuje jedince od onih koji imaju bratske i sestrinske odnose. Uključenost sudionika istraživanja u obiteljski život obitelji najboljeg prijatelja (PUO) kategoriziran je naknadno nakon uvida u kategorije uključenosti i predstavljen je dihotomno (postoji/ne postoji).

Tablica 3. Profil blizine i obiteljske uključenosti

\begin{tabular}{|c|c|c|c|c|}
\hline \multirow{13}{*}{$\begin{array}{c}\text { Profil } \\
\text { blizine i } \\
\text { obiteljske } \\
\text { uključenosti }\end{array}$} & Oznaka & Kategorija & Potkategorije i fre & ncije \\
\hline & \multirow{4}{*}{ PBS } & \multirow{4}{*}{$\begin{array}{l}\text { Procjena } \\
\text { blizine } \\
\text { stanovanja }\end{array}$} & Isto kućanstvo & 2 \\
\hline & & & Susjedi & 3 \\
\hline & & & Kvart & 3 \\
\hline & & & Grad & 4 \\
\hline & \multirow{4}{*}{ PRO } & \multirow{4}{*}{$\begin{array}{l}\text { Procjena } \\
\text { roditeljskog } \\
\text { odnosa }\end{array}$} & Poznanici & 3 \\
\hline & & & Prijatelji & 6 \\
\hline & & & Bliski prijatelji & 1 \\
\hline & & & Rodbina & 2 \\
\hline & \multirow{2}{*}{ PSB } & \multirow{2}{*}{$\begin{array}{c}\text { Profil } \\
\text { sestara /braće }\end{array}$} & Jedinac & 2 \\
\hline & & & Ima braću i sestre & 10 \\
\hline & \multirow{2}{*}{ PUO } & \multirow{2}{*}{$\begin{array}{c}\text { Profil } \\
\text { uključenosti u } \\
\text { obiteljski život }\end{array}$} & Postoji & 6 \\
\hline & & & Ne postoji & 6 \\
\hline
\end{tabular}

Kategorija blizine pokazala je raznolikost odgovora. Prostorna blizina bitna je za uspostavljanje odnosa najboljeg prijateljstva te se pokazalo da svi sudionici istraživanja imaju najboljeg prijatelja u istom gradu. Najčešće je riječ o susjedu ili osobi koja živi u istom kvartu, a u dva specifična slučaja riječ je o osobi koja živi u obitelji učenika. Na rezultate je zasigurno utjecala i veličina grada u kojemu je istraživanje 
provedeno. Riječ je o urbanom središtu i glavnom gradu koji svojom veličinom utječe na dinamiku međuljudskih i prijateljskih odnosa. $\mathrm{Na}$ rezultate je zasigurno utjecalo i postojanje upisnog područja kao sastavnog dijela mreža školskih ustanova, što znači da se učenici u osnovnu školu prijavljuju na temelju prostornog područja - prijavljenog prebivališta odnosno boravišta. Roditeljima je prilično bitno s kim se njihovo dijete druži te se roditeljski odnos pokazao važnim za izbor prijatelja. Većina roditelja međusobno ima prijateljski odnos s roditeljima najboljeg prijatelja njihova djeteta, pri čemu smo jedan odnos procijenili izrazito bliskim (zajednička ljetovanja i izleti). Tek manji dio ima odnos poznanika $(\mathrm{N}=3)$. Zanimljivo bi bilo istražiti jesu li ovi prijateljski odnosi postojali i prije ili su nastali nakon izbora najboljeg prijatelja, tj. je li prijateljski odnos roditelja utjecao na djetetov izbor prijatelja ili je to bilo obrnuto. Većina najboljih prijatelja imaju braću i sestre, a tek su dva »najbolja prijatelja« jedinci. Uključenost ispitanika u život obitelji najboljeg prijatelja pokazuje različite rezultate. Ove je odgovore bilo teško kategorizirati. Sudionici istraživanja uključenost su najčešće potvrđivali kategorijom koju nazivaju »prespavanac«, a koji označava jesam li ikada prespavao u obitelji mog najboljeg prijatelja. Izdvajali su i kategoriju igram se i družim s njegovim bratom ili sestrom te idem s njegovom obitelji na izlet i putovanje. Izostanak ovih oblika uključenosti u život najboljeg prijatelja kategorizirali smo kao nepostojanje uključenosti. Svjesni smo činjenice da bi najkvalitetniji odgovor na ovo pitanje dali roditelji koji nisu činili uzorak ovoga istraživanja. Stoga bismo u daljnja istraživanja uključili i roditelje čime bi podaci bili upotpunjeni s aspektom viđenja najboljeg prijateljstva iz roditeljskog kuta.

Drugo istraživačko pitanje usmjereno je na utvrđivanje hijerarhijske strukture dimenzija prijateljskog odnosa.

Tablica 4. Rezultati istraživanja hijerarhijske strukture dimenzija prijateljskog odnosa

\begin{tabular}{|l|c|c|c|c|c|c|c|c|c|c|c|c|}
\hline $\begin{array}{l}\text { Redni } \\
\text { broj }\end{array}$ & S1 & S2 & S3 & S4 & S5 & S6 & S7 & S8 & S9 & S10 & S11 & S12 \\
\hline I & 1. & 4. & 4. & 8. & 2. & 1. & 7. & 1. & 1. & 4. & 5. & 4. \\
\hline II & 5. & 5. & 1. & 6. & 5. & 3. & 6. & 2. & 2. & 5. & 4. & 5. \\
\hline
\end{tabular}




\begin{tabular}{|l|l|l|l|l|l|l|l|l|l|l|l|l|}
\hline III & 4. & 1. & 3. & 5. & 4. & 2. & 1. & 8. & 3. & 7. & 1. & 6. \\
\hline IV & 8. & 3. & 2. & 4. & 1. & 4. & 4. & 3. & 7. & 3. & 2. & 7. \\
\hline V & 6. & 2. & 5. & 1. & 6. & 5. & 5. & 5. & 4. & 6. & 3. & 3. \\
\hline VI & 3. & 6. & 7. & 7. & 3. & 8. & 2. & 4. & 5. & 2. & 7. & 8. \\
\hline VII & 7. & 8. & 8. & 3. & 8. & 7. & 3. & 6. & 8. & 1. & 8. & 1. \\
\hline VIII & 2. & 7. & 6. & 2. & 7. & 6. & 8. & 7. & 6. & 8. & 6. & 2. \\
\hline
\end{tabular}

Tablica 4 prikazuje rezultate istraživanja koji su odgovor na drugo istraživačko pitanje (»Kako izgleda hijerarhijska struktura dimenzija kvaliteta prijateljstva«). Učenici su dobili osam tvrdnji. Tvrdnje čine različite dimenzije prijateljskog odnosa. Ponuđene tvrdnje bile su:

I Daje mi do znanja koliko sam mu/njoj važan/važna.

II Brine o meni.

III Pouzdan/pouzdana je.

IV Lako se dogovorimo i riješimo problem.

$\mathrm{V}$ Pomaže mi.

VI Ugodan/ugodna je za druženje i zabavu.

VII Provodi vrijeme sa mnom (igra, razne aktivnosti).

VIII Povjerava mi o sebi nešto što drugima ne govori.

Iz navedenih tvrdnji vidljivo je da su učenici morali birati i utvrditi redoslijed između dimenzije priznanja, brige, pouzdanosti, povjerljivosti, rješavanja problema, pomoći, zabave i kvalitetnog provođenja vremena. Među ponuđenih osam tvrdnji učenici su se morali odlučiti koju dimenziju po svojoj osobnoj procjeni vrednuju kao najvažniju, kao i onu koju vrednuju kao najmanje važnu. Hijerarhijsku strukturu dimenzija trebali su utvrditi i za preostale dimenzije. Brojem 1 označavali su dimenziju koju smatraju najvažnijom, a brojem 8 onu koju smatraju najmanje važnom među ponuđenima. Ostali dijelovi hijerarhijske strukture označeni su brojevima od 2 do 7. 
Tablica 5. Hijerarhijska struktura dimenzija kvaliteta prijateljskog odnosa

\begin{tabular}{|c|c|c|c|c|c|}
\hline $\begin{array}{c}\text { RB } \\
\text { hijerarhija }\end{array}$ & $\begin{array}{c}\text { Kategorija } \\
\text { odnosa }\end{array}$ & $\mathrm{X}$ & Min & Max & Mo \\
\hline 1. & I & 3.58 & 1 & 8 & $1 ; 4$ \\
\hline 2. & III & 3,75 & 1 & 8 & 1 \\
\hline 3. & IV & 4,00 & 1 & 8 & $3 ; 4$ \\
\hline 4. & II & 4,08 & 1 & 6 & 5 \\
\hline 5. & V & 4,25 & 1 & 6 & 5 \\
\hline 6. & VI & 5,17 & 2 & 8 & 7 \\
\hline 7. & VIII & 5,58 & 2 & 8 & 6 \\
\hline 8. & VII & 5,67 & 1 & 8 & 8 \\
\hline
\end{tabular}

Kao najvažnija dimenzija pokazala se dimenzija priznanja. Učenici žele čuti od svojih prijatelja da su im najbolji prijatelji te da su im bitni i važni. Nakon toga slijedi dimenzija pouzdanosti. Kao najmanje važnom dimenzijom pokazalo se zajedničko provođenje vremena i intimitet. Usporedili smo rezultate za dvije grupe ispitanika s obzirom na spol. Hijerarhijska struktura pokazala se različitom.

Tablica 6. Hijerarhijska struktura dimenzija kvaliteta prijateljskog odnosa: djevojčice

\begin{tabular}{|c|c|c|c|c|c|}
\hline $\begin{array}{c}\text { RB } \\
\text { hijerarhija }\end{array}$ & $\begin{array}{c}\text { Kategorija } \\
\text { odnosa }\end{array}$ & $\mathrm{X}$ & Min & Max & Mo \\
\hline 1. & III & 3,17 & 1 & 5 & 4 \\
\hline 2. & IV & 3,67 & 1 & 8 & 4 \\
\hline $3 / 4$. & II & 4,17 & 1 & 5 & 5 \\
\hline $3 / 4$. & V & 4,17 & 1 & 6 & $5 ; 6$ \\
\hline $5 / 6$. & I & 5,00 & 1 & 8 & $1 ; 4$ \\
\hline $5 / 6$. & VIII & 5,00 & 2 & 7 & $2 ; 6 ; 7$ \\
\hline 7. & VI & 5,67 & 3 & 8 & 7 \\
\hline 8. & VII & 6,83 & 3 & 8 & 8 \\
\hline
\end{tabular}


Djevojčicama je najvažnija pouzdanost, a odmah poslije toga dogovaranje i rješavanje problema koji se javljaju u prijateljskom odnosu. Najmanje im je važno zajedničko provođenje vremena te zabava i druženje. Istraživanja o djevojčicama navode kako im je u toj dobi primarni fokus na intimitetu, bliskosti i ekskluzivnosti (manje grupe ili parovi) (Benenson, Apostoleris i Parnass, 1997) te da je interakcija djevojčica u visokoj povezanosti sa statusom u grupi odnosno da djevojčice biraju za prijateljice one djevojčice koje su istog sociometrijskog statusa (Gottman, 1986).

Tablica 7. Hijerarhijska struktura dimenzija kvaliteta prijateljskog odnosa: dječaci

\begin{tabular}{|c|c|c|c|c|c|}
\hline $\begin{array}{c}\text { RB } \\
\text { hijerarhija }\end{array}$ & $\begin{array}{c}\text { Kategorija } \\
\text { odnosa }\end{array}$ & $\mathrm{X}$ & Min & Max & Mo \\
\hline 1. & I & 3,67 & 1 & 7 & $1 ; 4$ \\
\hline 2. & II & 4,00 & 2 & 6 & $2 ; 5$ \\
\hline $3 / 4 / 5$. & III & 4,34 & 1 & 8 & 1 \\
\hline $3 / 4 / 5$. & IV & 4,34 & 2 & 7 & $3 ; 7$ \\
\hline $3 / 4 / 5$. & V & 4,34 & 3 & 5 & $3 ; 5$ \\
\hline 6. & VII & 4,50 & 1 & 8 & $1 ; 8$ \\
\hline 7. & VI & 4,67 & 2 & 8 & 2 \\
\hline 8. & VIII & 6,17 & 2 & 8 & $6 ; 8$ \\
\hline
\end{tabular}

Dječacima je najvažnije priznanje te međusobna briga. Najmanje važnim u hijerarhijskoj strukturi odnosa pokazali su se povjeravanje i intimitet o onome što nikome drugome nisu rekli, te zabava i druženje. Istraživanja o dječacima ukazuju da njima u toj dobi sociometrijski status drugih dječaka nije bitan, odnosno da ne postoji povezanost u kvantiteti interakcije između dječaka različitih statusa (Gottman, 1986). Također, druga istraživanja o dječacima navode kako oni naglasak stavljaju na zajedničko sudjelovanje u aktivnosti, igre, natjecanja (Erwin, 1993) te imaju manju razinu intimiteta (Burhmester, 1990, prema Erwin, 1993). 
Rezultati usporedbe pomalo iznenađuju. Prilikom intervjua bilo je vidljivo da su sve kategorije učenicima bitne i važne te da teško donose odluke. Objašnjenje za to leži u činjenici da je predmet izučavanja prijateljskih odnosa bio usmjeren isključivo na odnose u razrednom odjelu pri čemu zajedničko provedeno vrijeme učenici očigledno ne doživljavaju kao posebnu kategoriju u prijateljstvu. Naime, učenici su tijekom jedne godine proveli oko 1400 sati zajedno (sudionici istraživanja su učenici koji su pohađali nastavu u produženom boravku tijekom školske godine). Pretpostavljamo da bi rezultati bili drugačiji ako bismo predmet istraživanja prijateljskih odnosa ispitivali izvan kategorije razrednog odjela. Uvjerenja smo da bi se u tom slučaju kategorija zajednički provedenog vremena u hijerarhijskoj strukturi znatno više vrednovala. Razredni odjel se i u ovoj kategoriji pokazao kao presudan čimbenik pri utvrđivanju hijerarhijske strukture. Briga i priznanje za dječake te pouzdanost i rješavanje problema za djevojčice kategorije su koje su na vrhu hijerarhijske ljestvice, odnosno priznanje i pouzdanost ako rezultate gledamo u cjelini za desetogodišnjake unutar razrednog odjela.

Treće istraživačko pitanje usmjerilo se na karakteristike najboljeg prijatelja i idealnog prijatelja. Pitanja su bila otvorenog tipa. Tražio su opis karakteristika najboljeg prijatelja, kao i opis karakteristika idealnog prijatelja.

Tablica 8. Karakteristike najboljeg prijatelja

\begin{tabular}{|c|l|c|}
\hline \multirow{2}{*}{ Tema } & \multicolumn{2}{|c|}{ Kategorije i frekvencije } \\
\hline \multirow{3}{*}{$\begin{array}{c}\text { Karakteristike najboljeg } \\
\text { prijatelja }\end{array}$} & Razgovor & 4 \\
\cline { 2 - 3 } & Povjerljivost & 2 \\
\cline { 2 - 3 } & Intimitet & 2 \\
\cline { 2 - 3 } & Iskrenost & 2 \\
\cline { 2 - 3 } & Zabavnost & 1 \\
\cline { 2 - 3 } & Pomoć & 1 \\
\hline
\end{tabular}

Učenici su trebali izdvojiti koju karakteristiku svog najboljeg prijatelja najviše cijene, odnosno koja je karakteristika najboljeg prijate- 
lja bila ona koja je najviše pomogla u odluci da ga proglase najboljim prijateljem. Pri ovom zadatku najviše se istaknula kategorija ugodnog razgovora, a nakon toga kategorije povjerenja, intimiteta $\mathrm{i}$ iskrenosti. Slijede zabava i pomoć.

Tablica 9. Karakteristike idealnog prijatelja

\begin{tabular}{|c|c|c|c|c|}
\hline Tema & Kategorija & Potkategorija & Fre & acije \\
\hline \multirow{15}{*}{$\begin{array}{l}\text { Idealni } \\
\text { prijatelj }\end{array}$} & \multirow{6}{*}{$\begin{array}{l}\text { Moralne } \\
\text { vrijednosti }\end{array}$} & Dobrota & 9 & \multirow{6}{*}{23} \\
\hline & & Poštenje & 9 & \\
\hline & & Iskrenost & 4 & \\
\hline & & Povjerljivost & 3 & \\
\hline & & Vjernost & 1 & \\
\hline & & Pažljivost & 1 & \\
\hline & \multirow{3}{*}{$\begin{array}{l}\text { Karakteristike } \\
\text { ponašanja }\end{array}$} & Zabavnost & 4 & \multirow{3}{*}{6} \\
\hline & & Buntovnost & 1 & \\
\hline & & Dragost & 1 & \\
\hline & \multirow{3}{*}{$\begin{array}{l}\text { Spremnost za } \\
\text { pomoć }\end{array}$} & Pomoć u učenju & 3 & \multirow{3}{*}{5} \\
\hline & & Pomoć utjehom & 1 & \\
\hline & & Pomoć obranom & 1 & \\
\hline & \multirow{2}{*}{$\begin{array}{l}\text { Vrijeme i } \\
\text { aktivnosti }\end{array}$} & Razgovor & 3 & \multirow{2}{*}{4} \\
\hline & & Igra & 1 & \\
\hline & Priznanje & Pokazivanje ljubavi & 2 & 2 \\
\hline
\end{tabular}

U posljednjem pitanju pomaknuli smo se od realiteta i stvarnog prijatelja te su učenici dobili zadatak da zamisle idealnog prijatelja. U opisu idealnog prijatelja izdvojene su sljedeće kategorije: dobrota (9), poštenje (9), pomoć, utjeha i obrana (5), iskrenost (4), zabava i smijeh (4), razgovor i zajedničko vrijeme (3), čuvanje tajni (3), pokazivanje ljubavi (2), iskazivanje poštovanja (2), zajednička igra (1), vjernost (1), dragost (1), pažljivost (1) i opis prijatelja riječju 'fakin', tj. onaj 
koji voli raditi nestašluke - buntovnost (1). Navedene karakteristike kategorizirali smo u pet kategorija. Uvjerljivo najveću frekvenciju u poželjnim osobinama za najboljeg prijatelja čine moralne vrijednosti, a nakon toga slijede karakteristike ponašanja prijatelja i spremnost na pomoć. Zajedničko provedeno vrijeme i aktivnosti, kao i odavanje priznanja i pokazivanje privrženosti na dnu su ljestvice idealnog prijatelja. Kod moralnih vrijednosti posebno su se istaknuli dobrota i poštenje te iskrenost i povjerljivost.

Zanimljiv odgovor daje nam sudionik istraživanja koji za idealnog prijatelja navodi termin 'fakin' pri čemu jasno daje do znanja da $\mathrm{mu}$ je u prijateljstvu privlačna buntovnost osobe. Ovaj sudionik ovu dimenziju ističe kao prilično privlačnu pri čemu je ovu odrednicu tiho izgovarao, kao da se srami. Ovim odabirom želi naglasiti kako njegov izbor najboljeg prijatelja ide u smjeru osobe koja prijateljski odnos čini uzbudljivijim i dinamičnijim.

\section{Zaključna razmatranja}

U ovom je istraživanju utvrđen profil najboljeg prijatelja koji je dalje predstavljen kroz dva profila, pri čemu se prvi opći profil sastoji od šest kategorija, dok se profil blizine i roditeljske uključenosti sastoji od četiri kategorije. Spol se pokazao kao značajan prediktor pri čemu se znakovito preferiraju istospolna prijateljstva. Prilično je jasan profil dobi: desetogodišnjaci se uglavnom odlučuju za prijatelja svoje dobi unutar razrednog odjela, a iskustvo najboljeg prijateljstva nastaje na početku školovanja. Profil blizine i obiteljske uključenosti ukazuje na važnost blizine stanovanja (susjedstvo, kvart), kao i na značaj roditeljske uključenosti pri izboru prijatelja. Roditelji najboljih prijatelja najčešće su i međusobno prijatelji. Manjkavost istraživanja leži u činjenici da nismo uspjeli saznati je li to prijateljstvo roditelja nastalo prije ili nakon uspostave prijateljstva njihove djece što se svakako može istražiti u budućim istraživanjima ove vrste. Rezultati ukazuju i na potrebu studioznijeg pristupa pri proučavanju broja braće i sestara u obitelji kako ispitanika tako i najboljeg prijatelja te na značaj redoslijeda rođenja djeteta u obitelji.

Između ponuđenih dimenzija prijateljstva (priznanje, briga, pouzdanost, povjerljivost, rješavanje problema, pomoć, zabava i kvalitetno 
provođenje vremena) uočene su razlike u odgovorima dječaka i djevojčica. Djevojčicama je najvažnija pouzdanost, a odmah poslije toga dogovaranje i rješavanje problema koji se javljaju u prijateljskim odnosima. Dječacima je najvažnije priznanje te međusobna briga.

Pozitivno nas je iznenadio rezultat prema kojemu se među najpoželjnijim osobinama prijatelja navode one koje pripadaju vrlinama i moralnim vrijednostima. Kod moralnih vrijednosti posebno su se istaknuli dobrota i poštenje te iskrenost i povjerljivost.

Nova istraživačka pitanja i interes u međuvršnjačkim odnosima unutar razrednih odjela usmjerena su na utvrđivanje jasnije faktorske strukture dimenzija prijateljskog odnosa kako u kategoriji najboljeg prijatelja tako i u kategoriji prijateljskih odnosa općenito. Osim navedenog, interes se pojavljuje i u utvrđivanju povezanosti nekih novih varijabli koje nisu bile uključene u ovo istraživanje, kao što su sociometrijski status učenika, stupanj zadovoljstva školom i razrednim ozračjem te pristup proučavanju navedene problematike na drugačiji metodološki način.

\section{Literatura}

Arndorfer, Cara L.; Stormshak, Elizabeth A. (2008), »Same-sex versus other-sex best friendship in early adolescence. Longitudinal predictors of antisocial behavior throughout adolescence«, Journal of Youth and Adolescence, 37(9), str. 1059-1070. doi: https://doi.org/10.1007/s10964-008-9311-x

Asher, Steven R.; Parker, Jeffrey G. (1989), »Significance of peer relationship problems in childhood «, u: Schneider, Barry, H.; Attili, Grazia; Nadel, Josephine; Weissberg, Roger P. (ur.), Social Competence in Developmental Perspective, Amsterdam: Kluwer Academic, str. 5-23. doi: https://doi. org/10.1007/978-94-009-2442-0 1

Aukett, Richard; Ritchie, Jane; Mill, Kathryn (1988), »Gender differences in friendship patterns«, Sex Role, 19, str. 57-66. doi: https://doi.org/10.1007/ BF00292464

Bedeković, Vesna; Jurčić, Marko; Kolak, Ante (2009), »Sociometrijski status darovitog učenika i njegov položaj u društvenoj (razrednoj) eliti«, u: Gojkov, Grozdana (ur.), Daroviti $i$ društvena elita, Vršac: Visoka škola strukovnih studija Vršac, str. 80-91.

Bell, Sandra; Coleman, Simon (1999), »The anthropology of friendship. Enduring themes and future possibilities«, u: Bell, Sandra; Coleman, Simon (ur.), The Anthropology of Friendship, London: Berg, str. 1-20. doi: https://doi. org/10.4324/9781003135821-1 
Benenson, Joyce F.; Apostoleris, Nicholas H.; Parnass, Jodi (1997), »Age and sex differences in dyadic and group interaction«, Developmental Psychology, 33(3), str. 538-543. doi: https://doi.org/10.1037/0012-1649.33.3.538

Berndt, Thomas J. (1996), »Exploring the effects of friendship quality on social development«, u: Bukowski, William W.; Newcomb, Andrew F.; Hartup, Willard W. (ur.), The Company They Keep. Friendships in Childhood and Adolescence, Cambridge: Cambridge University Press, str. 346-366.

Bošnjak, Branko (1997), Drugo lice škole, Zagreb: Alineja.

Bukowski, William M.; Brendgen, Mara; Vitaro, Frank (2007), »Peers and socialization. Effects on externalizing and internalizing problems«, u: Grusec, Joan E.; Hastings, Paul D. (ur.), Handbook of Socialization. Theory and Research, New York: Guilford Press, str. 355-381.

Cillessen, Antonius H. N.; Rose, Amanda J. (2005), »Understanding popularity in the peer system «, Current Directions in Psychological Science, 14, str. $102-105$.

Connolly, Jennifer; Furman, Wyndol; Konarski Roman (2000), »The role of peers in the emergence of heterosexual romantic relationships in adolescence«, Child Development, 71(5) str. 1395-1408. doi: https://doi.org/10.1111/1467$\underline{8624.00235}$

De Wied, Minet; Branje, Susan J. T.; Meeus, Wim H. J. (2007), »Empathy and conflict resolution in friendship relations among adolescents «, Aggressive Behavior, 33, str. 48-55. doi: https://doi.org/10.1002/ab.20166

Dewey John (2007), The School and Society: Being Three Lectures, Cosimo, New York.

Gottman, John; Parker, Jeffrey (1986), Conversations of Friends. Speculations on Affective Development, Cambridge: CUP.

Huić, Aleksandra; Smolčić, Ivana (2016), »Strategije održavanja prijateljstva i zadovoljstvo istospolnim prijateljstvima. Efekti aktera i partnera«, Društvena istraživanja, 25(1), str. 63-83. doi: https://doi.org/10.5559/di.25.1.04

Kiper, Hanna; Mischke, Wolfgang (2008), Uvod u opću didaktiku, Zagreb: Educa.

Klarin, Mira (2000), Odnosi u obitelji is vršnjacima kao prediktori različitih aspekata prilagodbe u školi, doktorska disertacija, Zagreb: Odsjek za psihologiju Filozofskog fakulteta.

Klarin, Mira (2002a), »Dimenzije obiteljskih odnosa kao prediktori vršnjačkim odnosima djece školske dobi«, Društvena istraživanja, 11(4-5), str. 805-822.

Klarin, Mira (2002b), »Osjećaj usamljenosti i socijalno ponašanje djece školske dobi u kontekstu socijalne interakcije«, Ljetopis socijalnog rada, 9(2), str. 249-258.

Klarin, Mira (2006), Razvoj djece u socijalnom kontekstu - roditelji, vršnjaci, učitelji, Jastrebarsko: Naklada Slap.

Klarin, Mira; Proroković, Ana; Šimić Šašić, Slavica (2010), »Doživljaj prijateljstva i njegovi ponašajni korelati u adolescenata«, Pedagogijska istraživanja, 7(1), str. 7-22. 
Kolak, Ante; Markić Ivan (2018), Šimun ima prijatelje, Zagreb: KO-MA.

Krampač-Grljušić, Aleksandra; Kolak, Ante (2018), »Peer relations in inclusive classes «, Research in Pedagogy, 8(1), str. 17-35. doi: https://doi. org/10.17810/2015.68

Lacković-Grgin, Katica (2005), Psihologija adolescencije, Jastrebarsko: Naklada Slap.

Ladd, Gary W. (1990), »Having friend, keeping friends, making friends, and being liked by peers in the classroom: Predictors of children's early school adjustment?«, Child Development, 61, str. 1081-1100. doi: https://doi. org/10.2307/1130877

Ladd, Gary W.; Price, Joseph M. (1987), »Predicting children's social and school adjustment following the transition from preschool to kindergarten«, Child Development, 58, str. 1168-1189. doi: https://doi.org/10.2307/1130613

Ledbetter, Andrew M.; Griffin, Em; Sparks, Glenn G. (2007), »Forecasting 'friends forever'. A longitudinal investigation of sustained closeness between best friends«, Personal Relationships, 14, str. 343-350. doi: https://doi.or$\mathrm{g} / 10.1111 / \mathrm{j} .1475-6811.2007 .00158 . \mathrm{x}$

Maccoby, Eleanor (1998), The Two Sexes. Growing up Apart, Coming Together, Cambridge: Harvard University Press.

Maguire, Mary C.; Dunn, Judy (1997), »Friendships in early childhood and social understanding «, International Journal of Behavioral Development, 21(4), str. 669-686. doi: https://doi.org/10.1080/016502597384613

Majstrović, Ivana (2015), »Sociometrijski status darovitih učenika u razrednim odjelima«, diplomski rad, Zagreb: Filozofski fakultet.

Marton, Imola; Wiener, Judith; Rogers, Maria; Moore, Chris (2015), »Friendship characteristics of children with ADHD «, Journal of Attention Disorders, 9(10), str. 872-888. doi: https://doi.org/10.1177/1087054712458971

Pahl, Ray (2000), On Friendship, Cambridge: Polity.

Parker, Jeffrey G.; Asher, Steven R. (1993), »Friendship and friendship quality in middle childhood. Links with peer group acceptance and feeling of loneliness and social dissatisfaction«, Developmental Psychology, 2(4), str. 611-621. doi: https://doi.org/10.1037/0012-1649.29.4.611

Putarek, Vanja; Keresteš, Gordana (2012), »Tko je popularan u ranoj adolescenciji? Povezanost percipirane popularnosti sa spolom i usamljenosti«, Društvena istraživanja, 21(4), str. 949-968. doi: https://doi.org/10.5559/di.21.4.07

Rawlins, William K. (1992), Friendship Matters. Communication, Dialectics, and the Life Course, New York: Aldine de Gruyter.

Sippola, Lorrie K. (1999), »Getting to know the 'other'. The characteristics and developmental significance of other-sex relationships in adolescence«, Journal of Youth and Adolescence, 28(4), str. 407-418. doi: https://doi.or$\mathrm{g} / 10.1023 / \mathrm{A}: 1021660823003$ 
Trbojević, Jovana; Petrović, Jelica (2014), »Socijalne karakteristike dece koja uspostavljaju prijateljske dijade«, Primenjena psihologija, 7(3), str. 493-507. doi: https://doi.org/10.19090/pp.2014.3.493-507

Turnball, Ann. P., Blue-Banning, Martha; Pereira, Lourdes (2000), »Successful friendships of Hispanic children and youth with disabilities: An Exploratory study«, Mental Retardation, 38(2), 138-153.

Velki, Tena; Vrdoljak, Gabriela (2012), »Uloga nekih vršnjačkih i školskih varijabli u predviđanju vršnjačkoga nasilnog ponašanja«, Društvena istraživanja, 22(1), str. 101-120. doi: https://doi.org/10.5559/di.22.1.06

Vučetić, Marko (2007), »Prijateljstvo u Aristotelovoj filozofiji«, Filozofska istraživanja, 27(3), str. 571-579.

Žic Ralić, Anamarija; Ljubas, Marina (2013), »Prihvaćenost i prijateljstvo djece i mladih s teškoćama u razvoju«, Društvena istraživanja, 23(3), str. 435-453. doi: https://doi.org/10.5559/di.22.3.03

\title{
FRIEND RELATIONSHIPS AMONG PEERS IN THE CLASSROOM
}

\author{
Ante Kolak, Ivan Markić
}

This paper focuses on studying friend relationships in the classroom. Relationships between peers are exceptionally important in school age, and a lack of such relationships or continued difficulties with them can reflect on student successes, learning outcomes, and student perceptions of self, social status, social success, etc. The goal of the empirical part of the research was to examine the quality of friend relationships within the classroom in the category of 'best friend'. Three research questions arose from the research goal: What is the profile of friend relationships in the category of 'best friend'? What is the hierarchical structure of the quality dimensions of friendship in the categories offered? Which characteristics describe one's best friend and the ideal friend? The results of research affirm two profiles - a general one, and the profile of closeness and parental involvement. The affirmation of hierarchical structure pointed to the importance of care and recognition (among boys) and reliability and problem solving (among girls). The highest point in the hierarchy is held by the dimensions of recognition and reliability. The most significant characteristics that describe one's best friend include conversation and spending time together, trust and aid; the moral values of the friend are exemplified in an ideal friendship.

Key words: peer relationships, quality of friendship, classroom, friendship profile 